\title{
Przedsiębiorczość w badaniach empirycznych Instytutu Gospodarki Wyższej Szkoły Informatyki i Zarządzania w Rzeszowie
}

\begin{abstract}
Przedsiębiorczość a wyzwania globalizacji
Zagadnienie przedsiębiorczości jest współcześnie bardzo ważnym elementem rozważań w naukach społecznych. Znaczenie przedsiębiorczości rośnie wraz z rozwojem procesów określanych ogólnie mianem globalizacji. Jak podkreślają M.K. Nowakowski i J.J. Wajszczuk, to zjawisko ma charakter wielowymiarowy i ujawnia się w wielu dziedzinach życia ${ }^{1}$. Z punktu widzenia przedsiębiorczości, podstawowe trendy, na które należy zwrócić uwagę, to: rozwój technologiczny, znoszenie barier przepływu kapitału, zwiększanie dostępu do rynku globalnego oraz wzrost mobilności pracobiorców. Niebagatelne znaczenie ma również sfera kulturowa, która objawia się zmianą upowszechnianych systemów wartości i wzorców postępowania.

Z globalizacji wynika jeden podstawowy skutek determinujący funkcjonowanie jednostek i organizacji: wzrasta burzliwość otoczenia, a co za tym idzie - rośnie niepewność. Wyzwania wynikające z globalizacji wymienia np. J. Machaczka. Stwierdza on, że skuteczne funkcjonowanie $\mathrm{w}$ zglobalizowanym otoczeniu wymaga takich cech, jak: innowacyjność, elastyczność i dynamika². J. Penc dodaje, że globalizacja wyzwala presję na szybkość i efektywność wprowadzania nowych rozwiązań ${ }^{3}$. Z całą pewnością można więc powtórzyć śmiały pogląd $\mathrm{S}$. Kasiewicza, że współcześnie ujawniają się nowe formuły konkurowania, co przekłada się na zmianę celów, strategii ich osiągania i mierników działania ${ }^{4}$. Przedsiębiorczość można zatem uważać za odpowiedź organizacji i jednostek na wyzwania wynikające z globalizacji.
\end{abstract}

\section{Przedsiębiorczość jako zjawisko społeczno-gospodarcze}

Traktowanie przedsiębiorczości jako podstawowego czynnika podnoszącego konkurencyjność organizacji i jednostek wymaga uściślenia. Chodzi przede wszystkim o zrozumienie natury przedsiębiorczości oraz o przyjęcie czytelnej jej definicji. Jak ważne jest to zadanie, przekonuje M. Bratnicki, który wierzy, że zrozumienie natury przedsiębiorczości daje nowe spojrzenie na naturę człowieka i jego potencjał odnowy społeczno-ekonomicznej ${ }^{5}$.

\footnotetext{
${ }^{1}$ M.K. Nowakowski, J.J. Wajszczuk, Globalizacja i biznes. Powrót do źródet i wartości, „Organizacja i Kierowanie", 4/2003, s. 58.

2 J. Machaczka, Zmiana organizacji jako zjawisko wielowymiarowe, „Przegląd Organizacji”, 12/2004, s. 10.

${ }^{3}$ J. Penc, Zarzadzanie w Nowej Ekonomii, „Przegląd Organizacji”, 11/2001, s. 10.

${ }^{4}$ S. Kasiewicz, Klasyfikacja wskaźników oceny zarzadzania współczesnym przedsiębiorstwem, „Organizacja i Kierowanie", 3/1999, s. 25.

${ }^{5} \mathrm{M}$. Bratnicki, Refleksje teoretyka nad przedsiębiorczościq i przedsiębiorcami wspótczesnego biznesu, „Przegląd Organizacji”, 5/2001, s. 9.
} 
W literaturze ekonomicznej pojawiają się liczne przykłady definicji. Według niektórych autorów przedsiębiorczość należy rozumieć jako zachodzący w organizacjach proces „tworzenia nowej wartości, dokonujący się przez poświęcanie niezbędnego czasu i wysiłku oraz podejmowanie finansowego, psychicznego i społecznego ryzyka, który powoduje otrzymywanie rezultatów w postaci zysku pieniężnego oraz poczucia osobistej satysfakcji i niezależności”. ${ }^{6}$ M. Bratnicki wyraża podobną opinię, podkreślając, że przedsiębiorczość przejawia się inicjowaniem oraz aktywnym i kreatywnym rozwijaniem przedsięwzięć. ${ }^{7}$

W innym ujęciu przedsiębiorczość to cecha osobowości ,polegająca na zdolności i chęci ponoszenia ryzyka, skłonności do zachowań innowacyjnych, oraz podejmowanie działań w celu wykorzystania nadarzających się szans i okazji". ${ }^{8}$ Zwolennikami definiowania przedsiębiorczości w ten właśnie sposób są: T. Zaleśkiewicz ${ }^{9}$, B. Kożuch ${ }^{10}$ i J. Targalski ${ }^{11}$. Spojrzenie to uzupełnia A. Francik. Zgadza się ona, że w rzeczywistości przedsiębiorczość jest funkcją cech osobowościowych, ale jednocześnie wyraża się jako pewien sposób bycia lub zachowania się człowieka $^{12}$. P.F. Drucker mówi, że przedsiębiorczość ,jjest raczej sposobem postępowania niż cechą osobowości""13. Ten sposób działania charakteryzuje M. Bratnicki, wskazując na takie cechy, jak ukierunkowanie na rozwój, kreatywność czy umiejętność funkcjonowania w warunkach niepewności ${ }^{14}$. Również T. Listwan dostrzega takie przejawy przedsiębiorczości, jak elastyczność i kreatywność ${ }^{15}$. B. Kożuch dodaje w swoich rozważaniach, że działanie przedsiębiorcze ukierunkowane jest przede wszystkim na rozwój ${ }^{16}$. Niektórzy naukowcy nadają omawianemu zjawisku wręcz mistyczny charakter, definiując je jako ,zdolność do kreowania i budowania wizji czegoś z praktycznie niczego"' ${ }^{17}$. Z kolei S. Kwiatkowski traktuje przedsiębiorczość znacznie

${ }^{6}$ R.D. Hisrich, M.P. Peters, Enterpreneurship: Starting, Developing and Managing a New Venture, Irwin-McGraw-Hill, Chicago 1998, s. 9 [za:] T. Zaleśkiewicz, Przedsiębiorczość i podejmowanie ryzyka [w:] T. Tyszka (red.), Psychologia ekonomiczna, Gdańskie Wydawnictwo Psychologiczne, Gdańsk 2004, s. 307. Zob. także: T. Kraśnicka, Wokół pojęcia przedsiębiorczości, „Przegląd Organizacji”, 6/2002, s. 15. ${ }^{7}$ M. Bratnicki, Przedsiębiorczość i dynamika organizacji, „Organizacja i Kierowanie”, 2/2001, s. 4.

${ }^{8}$ Por. J. Sawicka, Psychospołeczne uwarunkowania przedsiębiorczości kobiet [w:] Aktywizacja zawodowa kobiet wiejskich poprzez rozwój drobnej przedsiębiorczości, SGGW, Warszawa 1998, t. 2 [za:] B. Kożuch, Zachowania przedsiębiorcze matych firm [w:] Przedsiębiorczość i rozwój matych i średnich przedsiębiorstw w XXI wieku, B. Piasecki (red.), UŁ, Łódź 2002, s. 239.

${ }^{9}$ T. Zaleśkiewicz, Przedsiębiorczość i podejmowanie ryzyka, op. cit., s. 308.

${ }^{10}$ B. Kożuch, Pojęcie i istota przedsiębiorczości [w:] Praktyczne problemy przedsiębiorczości, H. Wnorowski i A. Letkiewicz (red.), Wyd. Uniwersytetu w Białymstoku, Białystok 2001, s. 10 i 11.

${ }^{11}$ J. Targalski, Przedsiębiorczość i zarzqdzanie, Wyd. C.H.Beck, Warszawa 2003, s. 7.

${ }^{12}$ A. Francik, Przedsiębiorczość a innowacje, „Zeszyty Naukowe”, 444, AE, Kraków 1994, s. 15.

${ }_{13}^{13}$ P.F. Drucker, Natchnienie i fart, czyli innowacja i przedsiębiorczość, EMKA, Warszawa 2004, s. 28.

${ }^{14}$ M. Bratnicki, Przedsiębiorczość i przedsiębiorcy współczesnych organizacji, AE, Katowice 2002, s. 60.

${ }^{15} \mathrm{~T}$. Listwan, Wplyw potencjalu kompetencyjnego menedżerów na jakość kapitalu ludzkiego [w:] Kapitat ludzki a ksztaltowanie przedsiębiorczości, M. Juchnowicz (red.), Poltext, Warszawa 2004, s. 201.

${ }^{16}$ B. Kożuch, Pojęcie i istota przedsiębiorczości, op. cit., s. 17.

17 J.A. Timmons, Growing up big: Entrepreneurship and the Creation of High-Potential Ventures [w:] The Art and Science of Entrepreneurship, D.L. Sexton, R.W. Smilor (red.), Ballinger Pub. Comp., Cambridge 1986, s. 223. Zob. także: J.A. Timmons, New Venture Creation, Homewood, Irwin 1994, s. 7 i 8 [za:] D.F. Kuratko, R.M. Hodgetts, Entrepreneurship. A contemporary approach, Dryden Press, Orlando 1998, s. 32. 
bardziej racjonalnie, stwierdzając, że jest to pogoń za szansą rynkową ${ }^{18}$. Podobnie A.J. DuBrin, przejawy przedsiębiorczości widzi w gotowości podejmowania ryzyka i innowacyjności ${ }^{19}$.

Ostatnia grupa definicji odwołuje się do płaszczyzny organizacyjnej. W tym kontekście M. Pacholski i A. Słaboń określają przedsiębiorczość jako działalność gospodarczą, którą charakteryzuje innowacyjność i kreowanie wartości dodanej ${ }^{20}$. Takie cechy, zdaniem J. Lichtarskiego, pozwalają przedsiębiorstwu na efektywne i skuteczne podejmowanie inicjatyw gospodarczych ${ }^{21}$. O przedsiębiorczości organizacji mówi wprost W. Adamczyk, wymieniając przy okazji dwa przejawy tego zjawiska: innowacyjność i efektywność22. Ciekawe ujęcie przedsiębiorczości organizacyjnej proponuje M. Bratnicki, określając ją jako ,zespalanie tworzenia szans, zmiany, elastyczności, zróżnicowania, konkurencji z wykorzystywaniem szans, stabilnością, porządkiem, integracją, współpracą"23.

Podsumowując rozważania przybliżające naturę przedsiębiorczości, należy stwierdzić, że - niezależnie od przyjętej perspektywy (indywidualnej czy organizacyjnej) - przedsiębiorczość można zdefiniować jako trwałą kompetencję, przejawiającą się dynamicznym reagowaniem na zjawiska pojawiające się w otoczeniu i przynoszącą efekty w postaci przejścia na wyższy poziom rozwoju.

\section{Przedsiębiorczość jako zjawisko interdyscyplinarne i wynikające stąd uwagi metodologiczne}

Przedstawiony wyżej obraz przedsiębiorczości nie jest jednolity. Większość autorów zgadza się co do wynikających z niej zachowań, tj. aktywności, innowacyjności, elastyczności, podejmowania ryzyka, wykorzystywania szans czy też ukierunkowania na sukces. Jednak przedsiębiorczość jako zjawisko ujawnia się w tak wielu obszarach życia społeczno-gospodarczego, że zbudowanie jednolitej definicji jest bardzo trudne, a może nawet niemożliwe. Zatem warte przytoczenia są takie ujęcia przedsiębiorczości, które podkreślają ową interdyscyplinarność. W. Janasz proponuje, aby określać przedsiębiorczość mianem „kategorii wielowymiarowej, która wielokrotnie i przy pomocy różnych zmiennych jest wyjaśniana"24.

Z takiego ujęcia przedsiębiorczości wynika wprost sugestia odnosząca się do procedury badawczej. Prawidłowe wyjaśnienie zjawiska przedsiębiorczości wymaga korzystania z dorobku kilku dyscyplin naukowych: ekonomii, socjologii i psychologii. Można odwołać się także do - w pewnym sensie wykrystalizowanego już współcześnie - podejścia wynikającego z nauk o zarządzaniu, mimo że nie jest to jeszcze samodzielna dyscyplina nauki.

Można więc mówić o czterech podstawowych płaszczyznach badawczych zjawiska przedsiębiorczości: ekonomicznej, organizacyjnej, społecznej (kulturowej) oraz psychologicznej.

\footnotetext{
${ }^{18}$ S. Kwiatkowski, Perspektywy przedsiębiorczości w XXI wieku [w:] Przedsiębiorczość i rozwój matych $i$ średnich przedsiębiorstw w XXI wieku, B. Piasecki (red.), op. cit., s. 255.

${ }^{19}$ A.J. DuBrin, Praktyczna psychologia zarzadzania, PWN, Warszawa 1979, s. 501.

${ }^{20}$ M. Pacholski, A. Słaboń, Stownik pojęć socjologicznych, AE, Kraków 1997, s. 143.

${ }^{21}$ Podstawy nauki o przedsiębiorstwie, J. Lichtarski (red.), AE, Wrocław 1999, s. 16.

${ }^{22}$ W. Adamczyk, Przedsiębiorczość. Próba definicji, „Przegląd Organizacji”, 9/1996, s. 27.

${ }^{23}$ M. Bratnicki, Mitologia przedsiębiorczości organizacyjnej, „Przegląd Organizacji”, 5/2003, s. 6.

${ }^{24} \mathrm{~W}$. Janasz, Przedsiębiorczość w świetle uwarunkowań działalności gospodarczej [w:] Innowacje w rozwoju przedsiębiorczości w procesie innowacji, W. Janasz (red.), Difin, Warszawa 2004, s. 28.
} 
Ryc. 1. Cztery wymiary przedsiębiorczości

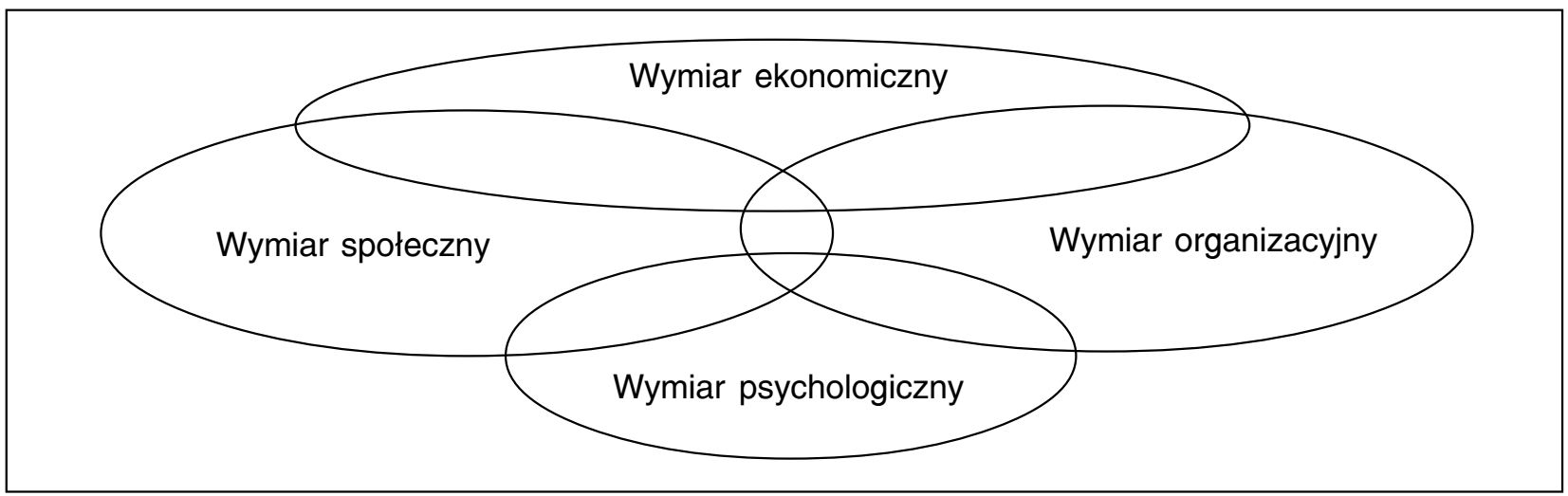

Źródło: opracowanie własne

Pierwsze - ekonomiczne ujęcie przedsiębiorczości odnosi się do zjawisk związanych z rozwojem sektora małych i średnich przedsiębiorstw (MSP). Przedsiębiorczość jest tutaj rozumiana jako proces rozpoczynania i prowadzenia działalności gospodarczej. Pytania badawcze, które mogą się pojawiać w ramach tego obszaru, dotyczą:

- czynników zewnętrznych determinujących rozwój małych i średnich przedsiębiorstw;

- roli sektora MSP w gospodarce kraju czy globalnej (m.in. udział w produkcji danego kraju, znaczenie na rynku pracy);

- procesu kształtowania się relacji między organizacjami różnego typu w zakresie tworzenia się i rozwoju klastrów innowacyjności;

- zmiany strukturalne w sektorze MSP, wynikające m.in. $\mathrm{z}$ absorpcji efektów rozwoju technologicznego oraz wykorzystania nowoczesnych metod zarządzania;

- terytorialnego zróżnicowania natężenia przedsiębiorczości.

Ujęcie ekonomiczne daje możliwość śledzenia zmian sektora MSP. Badania w tym zakresie opierają się najczęściej na danych statystycznych, a także ankietach, które dostarczają przede wszystkim danych ilościowych.

W innej perspektywie, organizacyjnej, ujmuje się przedsiębiorczość jako proces zachodzący wewnątrz organizacji, który ogólnie określany jest także jako zarządzanie przedsiębiorcze. Termin taki pojawia się w literaturze, $\mathrm{w}$ wypowiedziach niektórych naukowców. O zarządzaniu przedsiębiorczym pisze J.D. Antoszkiewicz, zwracając uwagę na pewne newralgiczne jego obszary, takie jak: klimat pracy, kultura organizacyjna, rozwój personelu czy niwelowanie barier rozwoju ${ }^{25}$. Przedsiębiorczość w kontekście organizacyjnym pojawia się także w wypowiedziach J. Machaczki i J. Targalskiego. Jest ono rozumiane szerzej niż samo zarządzanie. Pierwszy z wymienionych autorów stwierdza bowiem, że działanie przedsiębiorcze obejmuje zarządzanie przedsiębiorstwem ${ }^{26}$, a drugi w ramach procesu przedsiębiorczego wymienia właśnie zarządzanie przedsiębiorstwem ${ }^{27}$. Mogą się tutaj pojawić obszary badawcze, związane z takimi zagadnieniami, jak:

- uwarunkowania przywództwa i kształtowanie relacji wpływu (oraz zakres decentralizacji władzy);

\footnotetext{
${ }^{25}$ Por. J.D. Antoszkiewicz, Przedsiębiorczość w nowej roli [w:] Przedsiębiorczość i rozwój matych i średnich przedsiębiorstw w XXI wieku, B. Piasecki (red.), op. cit., s. 48 i 49.

${ }^{26}$ J. Machaczka, Zarzqdzanie rozwojem organizacji, Wydawnictwo Naukowe PWN, Warszawa-Kraków 1998, s. 48.

${ }^{27}$ Przedsiębiorczość a lokalny rozwój gospodarczy, J. Targalski (red.), AE, Kraków 1999, s. 135.
} 
- rola wizji, planowania strategicznego i myślenia strategicznego w rozwoju organizacji;

- efektywność i skuteczność procesu zarządzania;

- kształtowanie i rozwój personelu;

- mechanizmy motywowania personelu;

- proces innowacji i zmiany organizacyjnej oraz determinanty uelastyczniające reakcję organizacji na zmiany w turbulentnym otoczeniu.

Omówiony obszar badań empirycznych wymaga przeprowadzania ankiet i wywiadów. Możliwe jest też stosowanie innych metod zbierania danych, np. obserwacji. Niektóre typy danych ilościowych można pozyskiwać z dokumentów wewnętrznych organizacji (zwłaszcza jeśli chodzi o badanie efektów zarządzania, takich jak zysk, obrót, wielkość zatrudnienia, zadłużenie). Pozwala to na śledzenie procesu zarządzania jednostką gospodarczą i uzyskanych jego efektów.

Bliskie organizacyjnemu jest ujęcie społeczne przedsiębiorczości. Wychodzi ono jednak poza granice organizacji. Przedsiębiorczość ujawnia się także w sferze relacji międzyludzkich i w sferze kulturowej. Tego typu zjawisko ma charakter powszechny i nie może być zawężone do obszaru pojedynczej jednostki gospodarczej. Szczególnie pomocną dziedziną nauki jest w tym wypadku socjologia. W ujęciu socjologicznym przedsiębiorczość traktowana jest jako pewien specyficzny sposób zachowania się człowieka, który warunkowany jest czynnikami społecznymi, jak: pochodzenie, status ekonomiczny, płeć, wiek. Można też mówić o przyjmowaniu pewnej roli społecznej, która cechuje się właśnie przedsiębiorczością. Zatem w kręgu zainteresowań badaczy znajdzie się także identyfikacja elementów tej roli (zbioru oczekiwanych społecznie zachowań danej osoby), i to niekoniecznie tylko w kontekście gospodarczym. Oczywiście, ważna pozostaje cała sfera kulturowa, a szczególnie wzorce myślenia i postępowania oraz relacje międzyludzkie. W związku z tym można pokusić się o zaproponowanie przykładowych zagadnień interesujących dla badacza. Oto one:

- rola społeczna przedsiębiorcy w środowisku lokalnym (w tym zagadnienia etyki przedsiębiorczości i odpowiedzialności społecznej);

- identyfikacja czynników społecznych determinujących postawę przedsiębiorczą danego człowieka;

- określenie roli przedsiębiorcy (osoby przedsiębiorczej) oraz składników budujących te rolę (określone zachowania, obowiązki i uprawnienia);

- uwarunkowania przedsiębiorczości grupowej (wyznaczanie celów grupowych, zdobywanie pozycji lidera; kształtowanie wzorców, postaw, więzi społecznych);

- proces budowania klimatu wspierającego przedsiębiorczość (szczególnie chodzi o identyfikację barier współpracy i komunikacji).

Metody stosowane do badania kontekstu społecznego i kulturowego przedsiębiorczości pokrywają się z większością wymienionych wyżej (ankiety, wywiady, obserwacje). Dzięki takiemu spojrzeniu na przedsiębiorczość można odpowiedzieć w dużej mierze na pytanie, co determinuje przedsiębiorczość organizacji oraz przedsiębiorczość indywidualną.

Ujęcie psychologiczne przedsiębiorczości odnosi się właśnie do problematyki przedsiębiorczości indywidualnej. Właściwą do wyjaśniania tego zagadnienia dziedziną nauki jest psychologia. Przedsiębiorczość jest przez nią traktowana jako atrybut osobowości, czyli jej cecha. W związku z tym naukowcy starają się określić różnice między osobowością osoby przedsiębiorczej (najczęściej przedsiębiorcy) a osobowością osób, które przedsiębiorcze nie są. Problemy badawcze, jakie można tutaj zaproponować, mogą dotyczyć takich obszarów, jak:

- kształtowanie się osobowości przedsiębiorczej (wpływ czynników społecznych i biologicznych);

- identyfikacja cech przedsiębiorczych;

- przełożenie się cech osobowości na określone działania (w tym te o charakterze organizacyjnym czy grupowym). 
Ujęcie psychologiczne osobowości może być badane za pomocą metod kwestionariuszowych czy obserwacji. Możliwe jest wykorzystanie kwestionariuszy psychologicznych. Poznaje się w ten sposób proces kształtowania się zachowania danej osoby.

Niezależnie od tego, jaki wymiar przedsiębiorczości zostanie przyjęty w badaniu, warto zwrócić uwagę na pewien istotny fakt. Otóż podmiotem badania przedsiębiorczości są najczęściej przedsiębiorcy i prowadzone przez nich małe i średnie firmy. Realizacja badań w tej grupie społecznej jest bardzo trudna. Bariery wynikają przede wszystkim z postawy przedsiębiorców. Najczęściej nie są oni zainteresowani udziałem w badaniu, nieufnie podchodzą do ankieterów i przygotowanych narzędzi badawczych. Są też zwykle na tyle pochłonięci bieżącą działalnością firmy, że trudno oczekiwać, aby znaleźli czas na współpracę z instytucją badawcza. Problem ten jest w gruncie rzeczy najistotniejszy z punktu widzenia badań empirycznych. Często skutkuje to koniecznością stosowania próby celowej albo poważnymi trudnościami w zamknięciu fazy terenowej badania. $Z$ punktu widzenia instytucji badawczych konieczne jest zatem podejmowanie działań, które pozwalają zbudować jak najliczniejszą i możliwie reprezentatywną dla badanej populacji grupę przedsiębiorstw współpracujących. Pozwala to zmniejszyć nieufność, podnieść poziom zrozumienia potrzeb badawczych oraz zdecydowanie ułatwia prowadzenie badań empirycznych.

\section{Przedsiębiorczość w wybranych projektach badawczych Instytutu Gospodarki WSIiZ}

Efektywność i powodzenie procesu badawczego, oprócz wiedzy merytorycznej autorów oraz ich doświadczenia, wymaga współcześnie coraz większego wsparcia instytucjonalnego. Przykładem instytucji naukowo-badawczej jest Instytut Gospodarki - jednostka wyodrębniona w strukturze Wyższej Szkoły Informatyki i Zarządzania w Rzeszowie. Podstawowym celem, dla którego tego typu organizacja została utworzona, jest skoncentrowanie zasobów ludzkich i sprzętowych w ramach wyspecjalizowanej komórki. Uzyskuje się dzięki temu zmniejszenie barier logistycznych i finansowych, które niekiedy utrudniają prawidłową realizację badania. Bardzo ważny jest także rozwój zasobów ludzkich. Dzięki funkcjonowaniu w ramach interdyscyplinarnych zespołów badawczych osób o różnym doświadczeniu badawczym uzyskuje się dwojakiego rodzaju pozytywne efekty. Po pierwsze - jest to wymiana wiedzy na temat metodologii badawczych między przedstawicielami różnych dyscyplin naukowych. Po drugie - następuje efektywny proces zdobywania wiedzy praktycznej osób mniej doświadczonych; jest to swego rodzaj proces przyspieszenia przepływu wiedzy.

Instytut Gospodarki inicjuje i realizuje przedsięwzięcia badawcze o różnorodnym zakresie przedmiotowym. Jednym $z$ istotnych zagadnień jest właśnie przedsiębiorczość. Warto zwrócić uwagę na niektóre $\mathrm{z}$ badań poświęconych tej tematyce. Zostaną one omówione zgodnie z zaproponowaną wcześniej klasyfikacją wymiarów przedsiębiorczości.

W ramach podejścia ekonomicznego można rozważać badanie poświęcone wykorzystaniu koncepcji marketingowej i internetu w rozwoju przedsiębiorstw $\mathrm{z}$ sektora MSP $\mathrm{i}-\mathrm{w}$ niewielkim stopniu $-\mathrm{z}$ sektora przedsiębiorstw dużych. Zostało ono przeprowadzone na próbie 228 firm wybranych losowo. Zastosowany w badaniu kwestionariusz pozwala na budowanie dwóch wymiarów identyfikujących sytuację przedsiębiorstw. Pierwszy z tych wymiarów określa potencjał marketingowy firmy. Zwraca się w nim uwagę na takie czynniki, jak: potencjał rozwojowy, innowacyjność, badania marketingowe, atrakcyjność sektora oraz pozycję rynkowa. Podsumowując wyniki analizy, należy stwierdzić, że miernik zastosowany w badanej próbie uzyskuje wartości średnie. Drugi wymiar odnosi się do wykorzystania internetu. W jego skład wchodzą takie szczegółowe mierniki, jak wykorzystanie IT, wsparcie internetowe, obsługa 
on-line. Mimo dość powszechnego w badanych firmach dostępu do internetu, jego wykorzystanie w większości firm jest słabe, a wskaźnik przyjmuje wartości na pograniczu średnich i niskich.

Wyniki badań umożliwiają konstrukcję ogólnego, dwuwymiarowego modelu rozwojowego MAR-INT, który grupuje przedsiębiorstwa w dziewięciu klasach. Uwzględniają one trzy poziomy wartości mierników odpowiadających obu wymiarom analizy (potencjał marketingowy i wykorzystanie internetu). Dalsza konsolidacja pozwala na określenie trzech poziomów rozwoju przedsiębiorstw: 1. słaby rozwój - co najmniej jeden wymiar przyjmuje wartości niskie, a najwyżej jeden wartości średnie; 2. wysoki rozwój - co najmniej jeden wymiar przyjmuje wartości wysokie, a co najwyżej jeden wartości średnie; 3. średni rozwój - pozostałe klasy modelu.

Ryc. 2. Poziomy rozwoju przedsiębiorstw w modelu MAR-INT
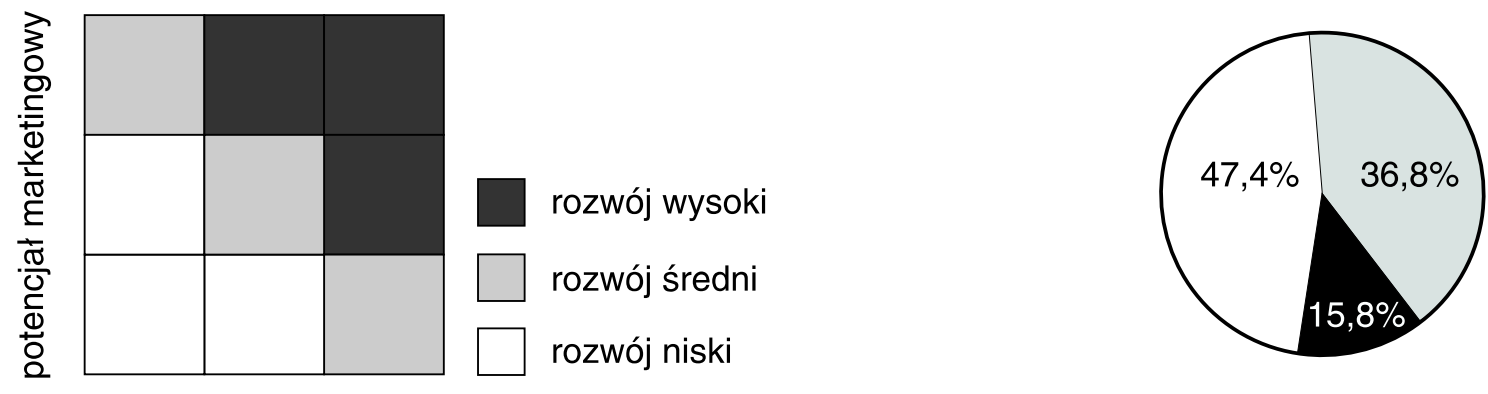

wykorzystanie internetu

Źródło: opracowanie własne na podstawie: Internet a zarządzanie marketingowe. Uwarunkowania rozwoju małych i średnich firm, S. Ślusarczyk, R. Góra, J. Strojny (red.), Wyższa Szkoła Informatyki i Zarządzania w Rzeszowie, Rzeszów 2005, s. 157 i 158.

Stosunkowo nieliczna grupa badanych firm w znaczącym stopniu realizuje już w swojej polityce rynkowej zasady wynikające z filozofii zarządzania marketingowego, jednocześnie wykorzystując w efektywny sposób narzędzia internetowe, rozszerzając zakres obsługi klienta i podnosząc jakość oferty. Największa grupa przedsiębiorstw znajduje się jednak na słabym poziomie rozwoju. Nie są to firmy innowacyjne, ich potencjał rozwojowy jest niewielki, a sektor (uwzględniając lokalny często zasięg oddziaływania) - nieatrakcyjny. Takie firmy nie wykorzystują także internetu. Przyczyny to bariery sprzętowe i finansowe oraz brak odpowiedniej wiedzy.

Kolejne badanie przedsiębiorczości może być klasyfikowane w ramach ujęcia społeczno-kulturowego. Jednym z podstawowych problemów badawczych jest tutaj określenie klimatu współpracy między przedstawicielami dwóch grup społecznych: przedsiębiorców i samorządowców. W próbach badawczych znalazło się 143 przedsiębiorców z sektora MSP oraz przedstawiciele samorządów lokalnych w 47 gminach. Badanie daje możliwość oceny otoczenia lokalnego (w tym funkcjonowania samorządów), a także określenia wizerunku przedsiębiorców oraz samorządowców.

Warto zwrócić uwagę, że przedsiębiorcy gorzej oceniają samych siebie niż samorządowcy. Wartość indeksów mierzących wizerunek typowego przedsiębiorcy wyniosła wśród przedsiębiorców 61,1 pkt., a wśród samorządowców - 63,5 pkt. Znacznie większe różnice występują w przypadku wizerunku typowego samorządowca. Przedsiębiorcy wystawiają oceny na poziomie 52,3 pkt. Samorządowcy są dla siebie znacznie bardziej pobłażliwi, a wartość indeksu wynosi 67,5 pkt. 
Ryc. 3. Wizerunek typowego przedsiębiorcy i typowego samorządowca

(pkt)

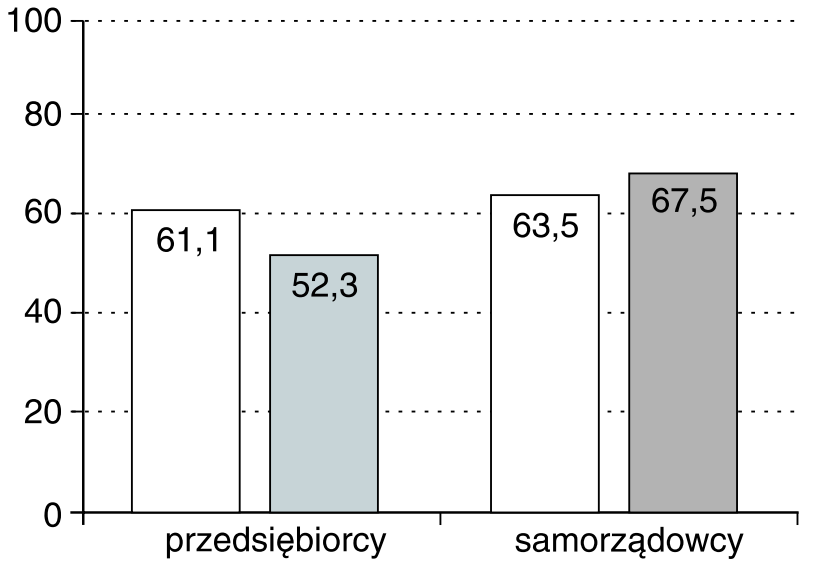

$\square$ wizerunek typowego przedsiębiorcy

wizerunek typowego samorządowca

Źródło: opracowanie własne

Respondenci w obu grupach społecznych mają także okazję odnieść się do sytuacji, w jakiej funkcjonuje sektor MSP, a która jest kształtowana przez czynniki lokalne. Przedsiębiorcy i samorządowcy różnią się opiniami co do stopnia wykorzystania instrumentów wspierania sektora MSP przez samorząd gminny. W opinii przedsiębiorców samorząd realizuje swoje zadania w tym względzie w sposób niewystarczający (41,2 pkt.). Samorządowcy uważają natomiast, że zadania te są wykonywane prawidłowo, a wykorzystanie instrumentów jest na dobrym poziomie (61 pkt.). Ocenie poddano także pracę lokalnych urzędników. Rozbieżności w badaniu są bardzo duże. Wartość miernika wśród przedsiębiorców wyniosła 47,8 pkt., a wśród samorządowców - aż 77,8 pkt.

Ryc. 4. Ocena lokalnych warunków funkcjonowania przedsiębiorstw

(pkt)

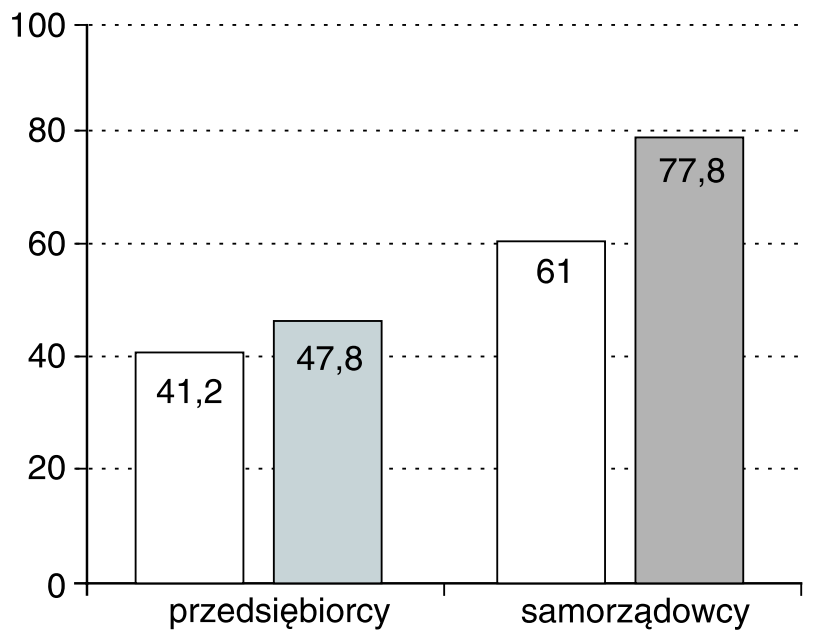

$\square$ wykorzystanie instrumentów MSP

praca urzędników samorządu lokalnego

Źródło: opracowanie własne

Między obiema grupami społecznymi istnieją znaczne różnice w ocenie rzeczywistości. Kładzie się to cieniem na klimat współpracy samorządu lokalnego z sektorem MSP. Przedsiębiorcy nie są zadowoleni z polityki samorządów gminnych. Wymagania co do jakości współpracy są bardzo wysokie. Tymczasem borykający się z problemami budżetowymi i przepisami urzędnicy, w wielu przypadkach nie z własnej winy, nie są w stanie im sprostać. 
Ostatnie badanie omówione w tym artykule wykorzystuje dwa pozostałe ujęcia przedsiębiorczości: organizacyjne i psychologiczne. Podstawowym problemem, którego wyjaśnieniu jest poświęcone niniejsze badanie, jest skuteczność przełożenia cech osobowościowych przedsiębiorcy na funkcjonowanie organizacji. Kontekst psychologiczny jest budowany przez tzw. teorię cech, która leży u podstaw rozważań nad wymiarami osobowości przedsiębiorczej. Jednocześnie uwzględnia się podejście sytuacyjne, gdyż zidentyfikowane cechy odnosi się do konkretnych obszarów zarządzania przedsiębiorstwem.

Badanie zrealizowano na próbie badawczej liczącej 141 przedsiębiorców z sektora MSP. Kwestionariusz ankiety składał się z dwóch części. Pierwsza pozwala na skonstruowanie modelu osobowości przedsiębiorczej, druga zaś wskazuje wymiary organizacji przedsiębiorczej. Pomiar odbywa się na trzech poziomach szczegółowości. Najbardziej ogólne mierniki charakteryzowane są przez parametry (wymiary) przedsiębiorczości: 1. na poziomie indywidualnym (osobowość przedsiębiorcza); 2. na poziomie organizacyjnym (działanie przedsiębiorcze). Do wymiarów osobowości przedsiębiorczej zaliczono: potrzeby osiagnięć, sterowność wewnętrzną oraz zdolności intelektualne. Wymiary działania przedsiębiorczego obejmują: myślenie strategiczne, kulturę współpracy oraz innowacyjność. Wymiary osobowości i działania przedsiębiorczego skonstruowano, opierając się na analizie czynnikowej, jakiej poddano wskaźniki, czyli najbardziej szczegółowe mierniki przedsiębiorczości. Dzięki analizie czynnikowej stało się możliwe takie pogrupowanie tych wskaźników, aby jak najbardziej rzetelnie oddawały rzeczywisty obraz przedsiębiorczości. Badanie pozwala zatem na pomiar natężenia przedsiębiorczości indywidualnej oraz przedsiębiorczości organizacyjnej na trzech poziomach szczegółowości. Dodatkowo weryfikuje się związek między osobowością przedsiębiorcy a przedsiębiorczością prowadzonej przez niego firmy. Do tego celu wykorzystuje się wskaźnik korelacji Pearsona.

Ryc. 5. Ocena lokalnych warunków funkcjonowania przedsiębiorstw

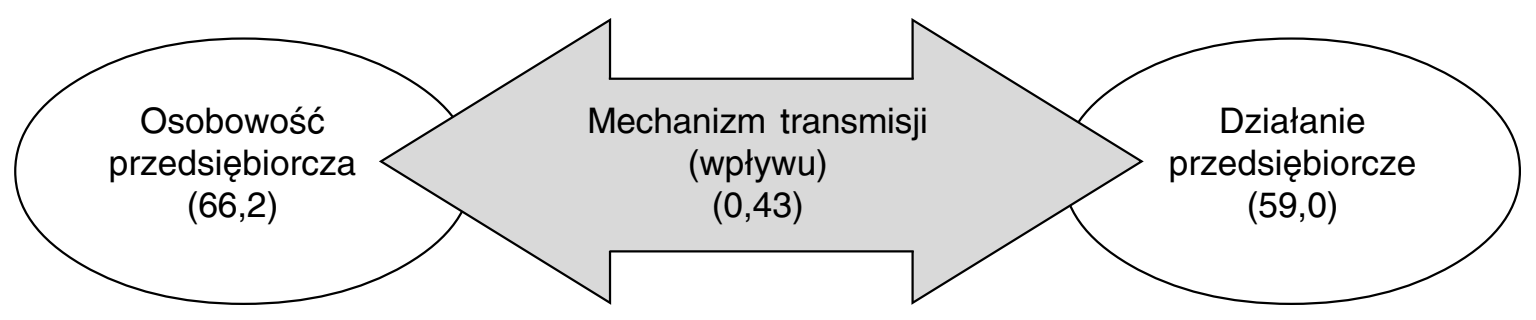

Uwaga. Wartości indeksów Osobowość przedsiębiorcza i Działanie przedsiębiorcze kształtują się w przedziale $i \in\langle 0 ; 100\rangle$, a miarą związku (mechanizmu transmisji) jest współczynnik korelacji Pearsona $r_{x y} \in\langle-1 ; 1\rangle$. Źródło: opracowanie własne

Wyniki badania pozwalają stwierdzić, że przedsiębiorczość indywidualna i organizacyjna w badanych firmach kształtuje się na poziomie średnim. Widać także przełożenie osobowości przedsiębiorczej właściciela firmy na sposób funkcjonowania prowadzonej przez niego organizacji. Uzyskana wartość korelacji na poziomie mierników ogólnych wynosi 0,43.

Oczywiście, podane w niniejszym artykule przykłady badań nie obejmują całego spektrum przedsięwzięć inicjowanych przez Instytut Gospodarki WSIiZ. Na zakończenie można wspomnieć inne inicjatywy badawcze odnoszące się do przedsiębiorczości. Oto one:

- analiza potencjału rozwojowego Podkarpacia (przedsiębiorczość traktowana jest jako jeden z czynników rozwoju regionalnego); 
- badanie osobowości przedsiębiorczej młodzieży aktywnej politycznie;

- badanie wpływu instrumentów budżetowych samorządu gminnego na rozwój przedsiębiorczości.

Podsumowując, można stwierdzić, że przedsiębiorczość jest jednym z głównych tematów badawczych Instytutu Gospodarki WSIiZ. Dzięki interdyscyplinarnemu podejściu do tego zagadnienia i współpracy naukowców reprezentujących różne dziedziny nauki, stało się możliwe badanie przedsiębiorczości przez pryzmat wszystkich ujęć badawczych: ekonomicznego, społecznego, psychologicznego i organizacyjnego.

\section{Literatura}

1. Adamczyk W., Przedsiębiorczość. Próba definicji, „Przegląd Organizacji”, 5/1996.

2. Bratnicki M., Mitologia przedsiębiorczości organizacyjnej, „Przegląd Organizacji”, 5/2003.

3. Bratnicki M., Przedsiębiorczość i dynamika organizacji, „Organizacja i Kierowanie”, 2/2001.

4. Bratnicki M., Przedsiębiorczość i przedsiębiorcy wspótczesnych organizacji, AE, Katowice 2002.

5. Bratnicki M., Refleksje teoretyka nad przedsiębiorczościq i przedsiębiorcami wspótczesnego biznesu, „Przegląd Organizacji”, 5/2001.

6. Kuratko D.F., Hodgetts R.M., Entrepreneurship. A contemporary approach, Dryden Press, Orlando 1998.

7. Drucker P.F., Natchnienie i fart, czyli innowacja i przedsiębiorczość, EMKA, Warszawa 2004.

8. DuBrin A.J., Praktyczna psychologia zarzqdzania, PWN, Warszawa 1979.

9. Francik A., Przedsiębiorczość a innowacje, „Zeszyty Naukowe”, 444, AE, Kraków 1994.

10. Innowacje w rozwoju przedsiębiorczości w procesie innowacji, W. Janasz (red.), Difin, Warszawa 2004.

11. Internet a zarzq̨dzanie marketingowe. Uwarunkowania rozwoju małych $i$ średnich firm, S. Ślusarczyk, R. Góra, J. Strojny (red.), Wyższa Szkoła Informatyki i Zarządzania w Rzeszowie, Rzeszów 2005.

12. Kapitał ludzki a kształtowanie przedsiębiorczości, M. Juchnowicz (red.), Poltext, Warszawa 2004.

13. Kasiewicz S., Klasyfikacja wskaźników oceny zarzadzania wspótczesnym przedsiębiorstwem, „Organizacja i Kierowanie", 3/1999.

14. Kraśnicka T., Wokót pojęcia przedsiębiorczości, „Przegląd Organizacji”, 6/2002.

15. Machaczka J., Zarzadzanie rozwojem organizacji, Wydawnictwo Naukowe PWN, Warszawa-Kraków 1998.

16. Machaczka J., Zmiana organizacji jako zjawisko wielowymiarowe, „Przegląd Organizacji”, 12/2004.

17. Nowakowski M.K., Wajszczuk J.J., Globalizacja i biznes. Powrót do źródet $i$ wartości, „Organizacja i Kierowanie", 4/2003.

18. Pacholski M., Słaboń A., Słownik pojęć socjologicznych, AE, Kraków 1997.

19. Penc J., Zarzadzanie w Nowej Ekonomii, „Przegląd Organizacji”, 11/2001.

20. Podstawy nauki o przedsiębiorstwie, J. Lichtarski (red.), AE, Wrocław 1999.

21. Praktyczne problemy przedsiębiorczości, H. Wnorowski, A. Letkiewicz (red.), Wyd. Uniwersytetu w Białymstoku, Białystok 2001.

22. Przedsiębiorczość a lokalny i regionalny rozwój gospodarczy, J. Targalski (red.), AE, Kraków 1999.

23. Przedsiębiorczość $i$ rozwój małych i średnich przedsiębiorstw w XXI wieku, B. Piasecki (red.), UŁ, Łódź 2002.

24. Psychologia ekonomiczna, T. Tyszka (red.), Gdańskie Wydawnictwo Psychologiczne, Gdańsk 2004.

25. Skica T., Strojny J., Tabasz W., Witkowski K., Samorzq̨d gminny a rozwój przedsiębiorczości. Podkarpaccy przedsiębiorcy wobec uwarunkowań wzajemnych relacji, raport z badań (maszynopis).

26. Skica T., Strojny J., Tabasz W., Witkowski K., Samorząd gminny a rozwój przedsiębiorczości. Podkarpaccy samorzadowcy wobec uwarunkowań wzajemnych relacji, raport z badań (maszynopis).

27. Targalski J., Przedsiębiorczość i zarzq̨zanie, Wyd. C.H.Beck, Warszawa 2003.

28. The Art and Science of Entrepreneurship, D.L. Sexton, R.W. Smilor (red.), Ballinger Publishing Company, Cambridge 1986. 


\section{The Entrepreneurship in Empirical Research in the Institute of Economics of University of Information Technology and Management in Rzeszów}

In this article the analysis of the development of entrepreneurship in Podkarpackie Province was presented. In the first part the author discusses the term ,entrepreneurship”, which is ambiguous and has various definitions in specialist texts. Then he presents results of the survey conducted among the entrepreneurs from the small \& medium business sector, and he outlines the subject of researches conducted by the Institute of Economics of University of Information Technology and Management in Rzeszów. 